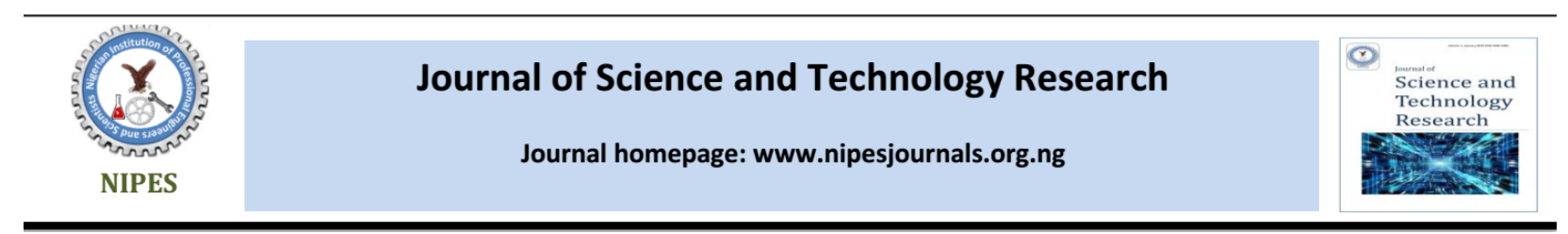

\title{
Characterization of Neem Seed Oil and its Biodiesel (B100)
}

${ }^{1}$ Taiwo, A. G. *, ${ }^{1}$ Ijaola, T. O., ${ }^{1}$ Lawal, S. O. and ${ }^{1}$ LanreIyanda, Y. A.

${ }^{1}$ Moshood Abiola Polytechnic, Science Laboratory Technology Department, P.M.B. 2210, Abeokuta, Ogun State, Nigeria.

\begin{tabular}{l} 
Article Info \\
\hline Keywords: \\
Feedstock, Neem seed oil, \\
Transesterification, \\
Neem seed biodiesel (B100), Methyl \\
ester
\end{tabular}

Received 18 April 2020

Revised 02 May 2020

Accepted 03 May 2020

Available online 01 June 2020

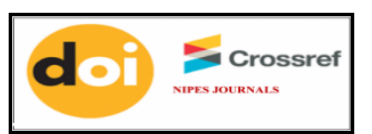

https://doi.org/10.37933/nipes/2.2.2020.18

\begin{abstract}
The current socio-economic, political and environmental challenges of fossil fuels led to alternative energy sources of bio-fuels like biogas, bio-alcohol, biodiesel etc which are sustainable, renewable and environmentally friendly. Neem biodiesel production involved oil extraction from the seed, moisture/FFA reduction then base transesterification reaction using the oil extracted, methanol (6:1), 1.0\% $\mathrm{KOH}$ at $60^{\circ} \mathrm{C}, 400 \mathrm{rpm}$ for 2 hours. The physico-chemical and fuel properties of the Neem seed oil biodiesel was analysed using standard analytical methods, and the data statistically using SPSS version 20.0. Most parametric values of the biodiesel were within the ASTM/EN standards except in the oil that requires some pretreatment. This biodiesel can be a major contribution now and in the future by meeting the petroleum diesel expected demand. As a result of this, it can be applied in diesel engines, plants with little or no modification and can also extend the life of diesel engines due to its more lubricating property.
\end{abstract}

https://nipesjournals.org.ng ISSN-2682-5821/@ 2020 NIPES Pub. All rights reserved.

\section{Introduction}

Everything in essence, is about energy. There is no doubt that energy is fundamental in development [1]. It is vital for internal and external security of a country and issues which are the core of environmental, socio-economic and political security challenges. There is concern that availability of petroleum products may be limited, declined in the nearest future and also continue to be expensive due to the massive increase in the fuel demand. An alternate fuel must be developed to reduce the gap between the fuel demand and fuel availability. Bio-fuels derived from oils and fats are found to be the most promising alternative fuel to petroleum diesel. Bio-fuels can be employed in existing diesel engines with minor or no modifications, also it can extend the life of diesel engines because it is more lubricating than petroleum diesel fuel [2]. Among the bio-fuels are biogas, bioalcohol, biodiesel but bio-alcohol seems to be the most common. However, there is growing main concern among scientists and economists, business people, managers and governments worldwide regarding shortages of energy, material resources and the increasing environmental issues [3]. It is obvious there is an urgent need to change the current situation with the need to search for energy alternatives involving locally available renewable resources. Biomass which is the fourth largest energy source after coal, oil and natural gas is currently the most important renewable energy option for now [4]. Commercial biomass can be used to provide heat and electricity as well as liquid biofuels and biogas for transport. Although there are risks related to such factors as supply, fuel quality, 
and price increases, as well as issues such as competition for land area and the degree of renewability of given resources. Sustainability reduces such risks, and can be supported by certification of substrates' origin [5].

Bio-energy is attractive at all stages of development due to its potential integration with all possible development strategies worldwide. The potential of bio-energy is widely recognized and it offers opportunities to address questions other than energy. Thus, it can be a solution for matters relating to economic, national, environmental and political security [6]. Moreover, bio-energy is based on resources that can be utilized on a sustainable basis all around the globe and can provide an effective option for the provision of energy services from a technical perspective. In addition, the benefits accrued go beyond energy provision, creating unique opportunities for regional development [7].

Biodiesel is a carbon-neutral liquid fuel made through trans-esterification reaction of altering the chemical properties of vegetable oils and fats using alcohol [8]. This simple process yields high conversion with glycerin as the only byproduct. It's very similar to petroleum diesel, but not identical. However, the difference is remarkably small when we compare the procedure for making biodiesel and petroleum diesel [9].

Neem seed oil is obtained from Neem plant Azadirachta indica derived from Persia, popularly known in Nigeria as Dongonyaro. The tree is a native of South East Asia and is a member of the Mahogany family Meliaceae. Also, large volumes of Neem seeds are generated in Nigeria as well as other countries which could be a possible nuisance in our rural and urban areas. Although, other oils can also be used for biodiesel production, but that extracted from Neem seeds is chosen because the seeds are readily available and not edible therefore, will not pose problem to humans in terms of food consumption, competition, security and also solve the challenge of pollution, management and treatment [10].

However, many researchers have analysed the nutritional and pharmaceutical values of the oil but search of the literature has shown that little information exist about the oil as a feedstock for producing and characterising biodiesel.

\section{Methodology}

\subsection{Sample Collection}

Neem seed (Azadirachta indica) were collected from the botanical garden of the University of Ibadan, Ibadan in Oyo State, Nigeria. It was identified according to the flora of West Africa in the Herbarium Unit of University of Ibadan where vouchers of each specimen were deposited.

\subsection{Sample Preparation}

The Neem seeds were sun-dried and the shells were manually cracked to obtain the kernels. The kernels were then milled and stored at $4^{\circ} \mathrm{C}$ until needed for analysis.

\subsection{Oil Extraction}

Oils from the milled seeds was exhaustively extracted with a Soxhlet apparatus using methanol as the solvent after which it was subjected to physico-chemical characterization using standard analytical methods on the appearance, water and sediment, viscosity, specific gravity, density, colour, $\mathrm{pH}$, sulphur, acid and FFA values, total,free and bound glycerine, flash, pour and cloud points, cetane number, saponification, iodine and peroxide values, molecular weight using A.O.A.C. (2000) and A.O.C.S. (2003). 


\subsection{Biodiesel Production}

The oil was heated in an oven at $100-120{ }^{\circ} \mathrm{C}$ for $20 \mathrm{~min}$ to reduce moisture/water concentration below $5 \mathrm{~g} / \mathrm{kg}$. The mechanism of reduction in free fatty acid was adopted for oils containing FFA up to $20 \%$, by lowering the acid value, making $300 \mathrm{~cm}^{3}$ of oil used to contain FFA less than $1 \%$. This is done by adding sufficient potassium hydroxide in $700 \mathrm{~g} / \mathrm{L}$ aqueous solution, heated at 30-35 ${ }^{\circ} \mathrm{C}$ to precipitate the solids and allowed to settle overnight, then the clear oil was decanted and the FFA determined according to ISO EN660, 1996.

The step by step approach used in the production of biodiesel during transesterification are;

(i) Measurement and heating of $300 \mathrm{~cm}^{3}$ of oil sample to a temperature of $60^{\circ} \mathrm{C}$

(ii) Purification and measurement of $1800 \mathrm{~cm}^{3}$ methanol to be used by re-distillation

(iii) Preparation and addition of the $1.0 \%$ potassium methoxide solution into the warm oil sample

(iv) Separation of the biodiesel from the lower layer (which comprises glycerol and soap)

(v) Washing of the biodiesel to remove any excess glycerol and soap that may remain

(vi) Drying of the washed biodiesel sample to remove excess methanol

(vii) Measuring, analysing and recording of the quantity and quality of the biodiesel produced.

The measuring of ratio 1:6 oil to methanol, $1.0 \%$ catalyst concentration, stirring time for $2 \mathrm{hrs}$ at $400 \mathrm{rpm}$, and the temperature at $60^{\circ} \mathrm{C}$ [14].

\subsection{Characterizations of the Oil and Biodiesel}

Standard procedures according to the American Oil Chemists' Society [11, 15], Official Methods of the American Oil Chemists' Society [12] and American Society for Testing and Materials (ASTM) methods of analysis were adopted in the characterization of the raw oil and the biodiesel produced. 2.5.1. Percentage yield

The percentage yield of the oil was calculated using Equation 1 [16]

Percentage yield $=\quad \frac{\text { Volume of samle extract }}{\text { Weight of sample taken }} \times 100$

\subsubsection{Appearance}

A physical eye check was carried on the sample.

\subsubsection{Water and Sediment content}

Sample of $5 \mathrm{~g}$ thoroughly mixed by stirring was weighed into a previously dried and weighed crucible with lid. The crucible without the lid was heated in an oven set at $105 \pm 1{ }^{\circ} \mathrm{C}$ for $1 \mathrm{hr}$. The crucible plus the sample was removed from the oven and covered with the lid and then cooled in a desiccator containing phosphorus pentoxide and weighed. It was later heated in the oven again for a further period of $1 \mathrm{hr}$, cooled and weighed. This process was repeated five times until change in weight between two successive observations was not noticed [11].

$\%$ Water and Sediment content $=\frac{\text { Sample loss of weight on drying }}{\text { Weight of sample taken }} \times 100$

\subsubsection{Viscosity}

Viscosity of the samples was measured at room temperature (in centistokes) with the Oswald kinematic viscometer equipped with an attached water bath and a thermostat [12].

\subsubsection{Specific gravity}

The specific gravity of the oil extracted and biodiesel were determined by means of a pyconometer [15].

\subsubsection{Density}

This was determined from specific gravity using Equation 3;

Density of sample $=$ Specific gravity $\mathrm{x}$ Density of water

Where density of water is $1 \mathrm{~g} / \mathrm{mol}$ [11]

\subsubsection{Colour}

The colour of the oil extracted and the diesel were determined by comparison with Lovibond glasses of known colour characteristics, and the colour was expressed as the sum total of the yellow and red 
slides used to match the colour of the diesel in a cell of the specified size in the Lovibond Tintometer [11].

\subsection{8. $\mathrm{pH}$, sulphur and carbon contents}

These parameters of the extracted oil and diesel were determined according to the method described in the American Oil Chemists Society [12] official and tentative methods [17,18].

\subsubsection{Acid value}

The acid value of the samples was determined by titrating the oils and the diesel in an alcoholic medium against standard $\mathrm{NaOH}$ solution [17].

\subsubsection{Free fatty acid}

The free fatty acid in the samples was determined by titrating each sample against potassium hydroxide using phenolphthalein as indicator [17].

\subsubsection{Total, free and bound glycerine}

Sample of $1 \mathrm{~g}$ each was measured into a $250 \mathrm{~cm}^{3}$ volumetric flask and $25 \mathrm{~cm}^{3}$ chloroform-methanol mixtures were added to dissolve the sample. About $10 \mathrm{~cm}^{3}$ of silisic acid and $10 \mathrm{~cm}^{3}$ alcoholic $\mathrm{KOH}$ were added to precipitate the glycerine. The supernatant obtained was decanted and the precipitate was dissolved in $10 \mathrm{~cm}^{3}$ of $0.2 \mathrm{M} \mathrm{H}_{2} \mathrm{SO}_{4}$ followed by the addition of $20 \mathrm{~cm}^{3} 0.05 \mathrm{M}$ sodium metaperiodate and $5 \mathrm{~cm}^{3}$ of sodium arsenite. The mixture was properly homogenised to get a uniform solution containing the total glycerine. Glycerine working standard of the range of 10 to 50 $\mu \mathrm{g} / \mathrm{cm}^{3}$ were prepared from $100 \mu \mathrm{g} / \mathrm{cm}^{3}$ stock glycerine and treated similarly as sample above. The absorbance of the samples and working standards were taken on a UV Spectrophotometer at a wavelength of $560 \mathrm{~nm}$ [12].

Total glycerine $(\mathrm{GT})=\frac{\text { Absorbance } x \text { Gradient Factor } x D f}{\text { Weight of sample } \times 10,000}$

Free glycerine was obtained by titrating the dissolved precipitate against $0.0 \mathrm{M} \mathrm{Na} 2 \mathrm{~S}_{2} \mathrm{O}_{3}$ using starch solution as indicator.

Free glycerine $(\mathrm{GF})=\frac{(\text { Blank titre }- \text { Sample titre }) \times M \text { of Na2S2O3 } \times 7.638}{\text { Weight of sample used }}$

Bound glycerine was calculated using the equation;

Bound glycerine $=$ Total glycerine - Bound glycerine

\subsubsection{Flash point}

This was done by determining the temperature at which the sample flashed when a test flame is applied under the conditions specified for the test [11].

\subsubsection{Pour point}

The pour point of the samples was determined by cooling the sample at a specified rate and the samples examined at $3^{\circ} \mathrm{C}$ intervals for flow characteristics. The lowest temperature at which samples movement was observed was then noted as the pour point [18].

\subsubsection{Cloud point}

The temperature at which a cloud is induced in the sample by cooling at a specified rate and examined at $3^{\circ} \mathrm{C}$ for first stage crystallization was determined according to A.O.C.S. (2000).

\subsubsection{Cetane number}

ASTM D613-18a (2008). Standard test method for cetane number of diesel fuel oil was used to determine the cetane number of the samples.

\subsubsection{Saponification value}

The samples were saponified by refluxing with excess alcoholic $\mathrm{KOH}$ solution. The alkali required for the saponification was determined by titration of the excess $\mathrm{KOH}$ with standard $\mathrm{HCl}$ [11]. 


\subsubsection{Iodine value}

Sample of $0.25 \mathrm{~g}$ was taken into carbon tetrachloride and treated with excess iodine monochloride solution in glacial acetic acid (Wijs solution). The excess of the iodine monochloride was then treated with potassium iodide and the liberated iodine was estimated by titration with sodium thiosulphate solution [11].

\subsubsection{Peroxide value}

The peroxide present was determined by titrating the sample against sodium thiosulphate solution in the presence of KI using starch as indicator [14].

\subsubsection{Molecular weight}

Saponification and acid values were first determined and then the molecular weight was calculated using Equation 7;

Mwt $=\frac{168300}{S V-A v}$

Mwt is the molecular weight, $\mathrm{SV}$ is the saponification value, Av is the acid value and 168300 is the Constant [19].

\subsubsection{Wet digestion}

Sample of $1.0 \mathrm{~g}$ of each (oven dried at $60^{\circ} \mathrm{C}$ ) was weighed into a $125 \mathrm{~cm}^{3}$ Erlemeyer flask previously washed with acid and distilled water. Perchloric acid of $4 \mathrm{~cm}^{3}, 25 \mathrm{~cm}^{3}$ concentrated $\mathrm{HNO}_{3}$ and 2 $\mathrm{cm}^{3}$ concentrated $\mathrm{H}_{2} \mathrm{SO}_{4}$ under a fume hood were added. The contents were mixed and heated gently at $120{ }^{\circ} \mathrm{C}$ on a hot plate under perchloric acid in a fume hood and heating continued until dense white fumes appear. Presence of any traces of carbon remain, then the flask was allowed to cool and added $2 \mathrm{~cm}^{3}$ concentrated $\mathrm{HNO}_{3}$, digested again to the fuming stage and finally, heated strongly at 150 to $240{ }^{\circ} \mathrm{C}$ for half a minute. It was allowed to cool and added $50 \mathrm{~cm}^{3}$ distilled water then boiled for half a minute on the same plate at a $150{ }^{\circ} \mathrm{C}$. The solution was cooled and filtered completely with Whatman No. 42 filter paper, then made up to $100 \mathrm{~cm}^{3}$ mark in Pyrex volumetric flask with distilled water. The solution was analysed for Aluminium by Atomic Absorption Spectrometry and Potassium by Flame Emission Spectrometry at each wavelength of maximum absorption and emission.

\subsection{Statistical analysis}

Results obtained were expressed as the mean of three separate observations. The data was statistically analyzed with 2-way analysis of variance (ANOVA) using SAS software. The means were compared by Duncan's Multiple Range Test at $5 \%$ level of significance $(p \leq 0.05)$.

\section{Results and Discussion}

Table 1.0: Physico-chemical properties of Neem seed oil and it's Biodiesel (B100)

\begin{tabular}{llll}
\hline Parameters & $\begin{array}{l}\text { Neem seed oil } \\
\text { extract }\end{array}$ & $\begin{array}{l}\text { Neem seed oil } \\
\text { Biodiesel }\end{array}$ & $\begin{array}{l}\text { PD/BD ASTM, } \\
\text { 2008B, 2011 } \\
\text { /EN, 2009, 2010 } \\
\text { Standard }\end{array}$ \\
& & & \\
& & & Varies \\
Appearance & Golden yellow & Light golden yellow & \\
& viscous liquid & viscous liquid & \\
Yield $(\%)$ & 41.5 & 80.9 & 96.5 min \\
pH & 6.10 & 6.69 & Varies \\
Viscosity $\left(\mathrm{mm}^{2} / \mathrm{s}\right.$ at $\left.40^{\circ} \mathrm{C}\right)$ & $31.99 \pm 0.20$ & $4.99 \pm 0.10$ & $1.9-6.0$ \\
Specific gravity $(\mathrm{g} / \mathrm{g})$ & $0.92 \pm 0.01$ & $0.90 \pm 0.00$ & 0.88 \\
Density $\left(\mathrm{g} / \mathrm{cm}^{3}\right)$ & $0.91 \pm 0.00$ & $0.89 \pm 0.00$ & $<0.86$ \\
Water and sediment $(\%)$ & $1.82 \pm 0.20$ & $0.95 \pm 0.01$ & 0.05 \\
Colour $(\mathrm{Hz})$ & $4.15 \pm 0.30$ & $3.55 \pm 0.20$ & $\leq 4.00$ \\
Flash point $\left({ }^{\circ} \mathrm{C}\right)$ & $192.70 \pm 2.00$ & $157.52 \pm 1.00$ & 93.0 min \\
Pour point $\left({ }^{\circ} \mathrm{C}\right)$ & $11.00 \pm 0.10$ & $8.30 \pm 0.20$ & -15 to 10
\end{tabular}


Taiwo, A. $G$ et al./ NIPES Journal of Science and Technology Research

2(2) 2020 pp. $178-187$

\begin{tabular}{llll} 
Cloud point $\left({ }^{\circ} \mathrm{C}\right)$ & $15.00 \pm 0.20$ & $10.20 \pm 0.40$ & -3 to 12 \\
Cetane Number & 49.20 & 53.75 & 47 min \\
Acid value $(\mathrm{mgKOH} / \mathrm{g})$ & $20.90 \pm 0.30$ & $9.60 \pm 0.02$ & $0.50 \max$ \\
Free fatty acid $(\mathrm{mgKOH} / \mathrm{g})$ & $10.45 \pm 0.20$ & $4.80 \pm 0.01$ & $0.25 \max$ \\
Total Glycerin $(\%)$ & $0.25 \pm 0.03$ & $0.15 \pm 0.02$ & 0.24 \\
Bound Glycerin $(\%)$ & $0.16 \pm 0.02$ & $0.10 \pm 0.01$ & 0.24 \\
Free Glycerin $(\%)$ & $0.09 \pm 0.01$ & $0.05 \pm 0.00$ & 0.02 \\
Iodine value $(\mathrm{g} / 100 \mathrm{~g})$ & $76.50 \pm 0.30$ & $60.93 \pm 0.20$ & $120 \max$ \\
Saponification value $(\mathrm{mgKOH} / \mathrm{g})$ & $196.89 \pm 0.04$ & $178.45 \pm 0.30$ & $\mathrm{NA}$ \\
Peroxide value $(\mathrm{mEq} / \mathrm{kg})$ & $8.15 \pm 0.10$ & $5.75 \pm 0.02$ & $10-20(\mathrm{Oil})$ \\
Carbon residue $(\%)$ & $0.22 \pm 0.02$ & $0.16 \pm 0.01$ & $0.05 \max$ \\
Molecular weight $(\mathrm{g} / \mathrm{mole})$ & 315.50 & 289.30 & Varies \\
Sulphur $(\mathrm{mg} / \mathrm{kg})$ & $7.30 \pm 0.30$ & $4.80 \pm 0.02$ & $10 \max$ \\
$\mathrm{K}(\mathrm{mg} / \mathrm{kg})$ & $0.05 \pm 0.00$ & $0.02 \pm 0.00$ & $0.01-0.20$ \\
$\mathrm{Al}(\mathrm{mg} / \mathrm{kg})$ & $0.33 \pm 0.10$ & $0.28 \pm 0.02$ & 0.50 \\
\hline
\end{tabular}

\subsection{Physico-chemical properties}

Table 1.0 shows the physico-chemical properties of Neem seed oil and it's biodiesel (B100), with the appearance of the samples being similar. The appearance of Neem seed oil was golden yellow liquid but Dangarembizi et al. (2015) had yellow green solid oil. The appearance of Need oil biodiesel was light golden yellow liquid but Ibikunle et al. (2019) had golden viscous liquid in both the oil and biodiesel produced. Appearance varies in ASTM/EN limit because the difference in chemical component of samples is responsible for this observation [27].

The yield of Neem seed oil of $41.5 \%$ is much higher than that of Dangarembizi et al. (2015) who obtained 9.53\%, Neem seed oil biodiesel yield was $80.9 \%$ which is lower than ASTM, 2011/EN, 2010 standard of $96.5 \%$ min. The oil yield is dependent on the physico-chemical composition, oil:solvent ratio and type, temperature and time while that of the biodiesel also includes these with catalyst type and concentration, stirring speed, transesterfication type, separation and washing methods involved [28].

$\mathrm{pH}$ of Neem seed oil was 6.10 , which is slightly acidic and shows that the oil requires pre-treatment to reduce the acidity so as to make it suitable for biodiesel production. Neem seed biodiesel $\mathrm{pH}$ was 6.69 , tending neutral but differs in ASTM/EN standard.

The viscosity of Neem seed oil was $31.99 \pm 0.20 \mathrm{~mm}^{2} / \mathrm{s}$ at $40^{\circ} \mathrm{C}$, Neem seed oil biodiesel was $4.99 \pm 0.10 \mathrm{~mm}^{2} / \mathrm{s}$ at $40^{\circ} \mathrm{C}$ was lower than the oil due to transesterification reaction, but within ASTM, (2008)/EN, (2009) standard of $1.90-6.00 \mathrm{~mm}^{2} / \mathrm{s}$ at $40^{\circ} \mathrm{C}$. The Neem seed oil biodiesel value is lower than those of Aransiola et al. (2011), Taiwo et al. (2016) and De Lima da Silva et al. (2009). Less viscosity gives greater ease of fuel movement for better and faster fuel atomization and decrease in ignition delay.

Specific gravity and density of Neem seed oil were $0.92 \pm 0.01 \mathrm{~g} / \mathrm{g}$ and $0.91 \pm 0.00 \mathrm{~g} / \mathrm{cm}^{3}$ respectively. The high values are because the weight is heavy due to some impurities that might be present which calls for pre-treatment of the oil to make them biodiesel production suitable (Moser, 2009). Those of Neem seed oil biodiesel was $0.90 \pm 0.00 \mathrm{~g} / \mathrm{g}$ and $0.89 \pm 0.00 \mathrm{~g} / \mathrm{cm}^{3}$ respectively, which are lower than those of the oil due to trans-esterification process but higher than ASTM, (2008b) standard of $<0.88 \mathrm{~g} / \mathrm{g}$ and $<0.86 \mathrm{~g} / \mathrm{cm}^{3}$ respectively. The density value is also higher than that of Ali et al. (2013) of $0.88 \mathrm{~g} / \mathrm{cm}^{3}$ and $0.61 \mathrm{~g} / \mathrm{cm}^{3}$ for Neem seed oil and biodiesel respectively. The specific gravity value of biodiesel is less than that of Aransiola et al. (2011) but density value is lower than that of De Lima da Silva et al. (2009). High values could be because the weight is heavy due to some Impurities that might be present [32]. Density influences the air-fuel ratio due to mass of the oil and the biodiesel.

The water and sediment was 
$1.82 \pm 0.20 \%$ in Neem seed oil, which is higher than $0.95 \pm 0.01 \%$ in Neem seed oil biodiesel thus it needs pre-treatment of heating, filtration to make it suitable for transesterification reaction. The biodiesel value is above $0.05 \%$ ASTM, (2008)/EN, (2009) standards. The value is lower than that of Taiwo et al. (2016) but higher than that of De Lima da Silva et al. (2009). Water and sediments are byproducts of storage due to ester oxidation, reactive glycerides and algae growth.

The colour value of the Neem seed oil was $4.15 \pm 0.30 \mathrm{~Hz}$ which is higher than that of Neem seed oil biodiesel $(3.55 \pm 0.20 \mathrm{~Hz})$ but within permissible ASTM/EN standard of $\leq 4.00 \mathrm{~Hz}$. Colour value of the biodiesel is less than that of Taiwo et al. (2016). The difference in chemical component of samples could be responsible for the variations observed [27].

The flash point of Neem seed oil was $192.70 \pm 2.00^{\circ} \mathrm{C}$ which is higher than that of Neem seed oil biodiesel $\left(157.52 \pm 1.00^{\circ} \mathrm{C}\right)$, but within the permissible standard of $93.0^{\circ} \mathrm{C}$ max of ASTM, 2011/EN, 2010. The value is higher than values were reported by Tyson, (2001), De Lima da Silva et al. (2009) $\left(93^{\circ} \mathrm{C}\right)$. Flash point is the safety requirements in handling and storage of fuel due to its hazardous nature and biodiesel is safer than petroleum diesel due to high values.

Pour point is the lowest temperature at which biodiesel can still move. Neem seed oil value was $11.00 \pm 0.10^{\circ} \mathrm{C}$, which is higher than that of Neem seed oil biodiesel $\left(8.30 \pm 0.20^{\circ} \mathrm{C}\right)$, with both within ASTM, 2011/EN, 2010 of -15 to 10, which shows that the biodiesel except the oil will not perform better due to the presence of saturated fatty acid chains and monoglycerides [35]. The pour point value was greater than that of Aransiola et al. (2011) and Taiwo et al. (2016).

Cloud point is an important parameter for low temperature operation of fuel due to solidification of heavier components in biodiesel resulting in crystals within the body when cooled. Neem seed oil value was $15.00 \pm 0.20^{\circ} \mathrm{C}$, which is higher than that of Neem seed oil biodiesel $\left(10.20 \pm 0.40^{\circ} \mathrm{C}\right)$ but above ASTM, 2011/ EN, 2010 of -3 to $12{ }^{\circ} \mathrm{C}$. This also shows that the oil will perform better in low temperature than the biodiesel. The cloud point values were greater than that of Aransiola $e t$ al. (2011) and Taiwo et al. (2016).

Cetane number of Neem seed oil was 49.20 which was lower than that of Neem seed oil biodiesel (53.75), but within ASTM, 2011/EN, 2010 standard of 47.00 min and higher than that of De Lima da Silva et al. (2009) (50.00). Cetane number is critical in cold starting engine conditions because low values results in long ignition delay and high in faster auto-ignition [36].

Free fatty acid and acid values of the Neem seed oil was $10.45 \pm 0.20 \mathrm{mgKOH} / \mathrm{g}$ and $20.90 \pm 0.30$ $\mathrm{mgKOH} / \mathrm{g}$ which is more than double that of Neem seed oil biodiesel of $4.80 \pm 0.01 \mathrm{mgKOH} / \mathrm{g}$ and $9.60 \pm 0.02 \mathrm{mgKOH} / \mathrm{g}$. This necessitates the pre-treatment of the oil for reduction in acidity by addition of excess $\mathrm{KOH}$ to enhance biodiesel process and production. The biodiesel value is above the ASTM, (2011)/EN, (2010) standard of 0.25 to $0.50 \mathrm{mg} / \mathrm{KOH} / \mathrm{g}$ which calls for further treatment to reduce the acidity to permissible limit. Also the values are less than those of Aransiola et al. (2011) and Taiwo et al. (2016) but higher than that of Ibikunle et al. (2019). Acid value is the level of residual organic acids due to oxidation leading to deterioration.

Total and bound glycerine values in Neem seed oil was $0.25 \pm 0.03 \%$ and $0.16 \pm 0.02 \%$, which was higher than that of Neem seed oil biodiesel $(0.15 \pm 0.02 \%$ to $0.10 \pm 0.01 \%)$, with all the values within the ASTM, 2011/EN, 2010 standard of $0.24 \%$ which is an indication of more complete transesterification process in biodiesel production. The total and bound glycerine values were greater than those of Aransiola et al. (2011) and Taiwo et al. (2016).

Free glycerine values in Neem seed oil was $0.09 \pm 0.01 \%$ which was higher than that of Neem seed 
oil biodiesel $(0.05 \pm 0.00 \%)$, but all was above the permissible standard of $0.02 \%$. Iodine value of Neem seed oil was $76.50 \pm 0.30 \mathrm{gI}_{2} / 100 \mathrm{~g}$ which is higher than of Dangarembizi et al. (2015) and Neem seed oil biodiesel of $60.93 \pm 0.20 \mathrm{gI}_{2} / 100 \mathrm{~g}$, but all were within the ASTM, 2011/EN, 2010 Standard of $120 \mathrm{gI}_{2} / 100 \mathrm{~g}$ max. Iodine value is less than those of Aransiola et al. (2011), Taiwo et al. (2016) and De Lima da Silva et al. (2009) but higher than that of Ibikunle et al. (2019). Low value could be as a result of the destruction of double bonds and vice versa, high values results in propensity for polymerization leading to deposit formation [36].

Saponification value of Neem seed oil was $196.89 \pm 0.04 \mathrm{mgKOH} / \mathrm{g}$, which was lower than that obtained by Dangarembizi et al. (2015) but higher than those of Neem seed oil biodiesel $(178.45 \pm 0.30 \mathrm{mgKOH} / \mathrm{g})$. The value was close to that of Aransiola et al. (2011), but lower than those of Reed et al. (1994) (155.50 to $159.70 \mathrm{mgKOH} / \mathrm{g}$ ). The variation in the saponification value shows the differences in chain lengths of the free fatty acids present the samples. Long chain fatty acids found in fat and oil have low saponification value because they have a relatively fewer number of carboxylic functional groups per unit mass, therefore has high molecular weight [38]. Standard saponification values for biodiesel are not stated but all values observed were within the standard value for oil of 192-198 $\mathrm{mgKOH} / \mathrm{g}$.

The peroxide value of the Neem seed oil was $8.15 \pm 0.10 \mathrm{mEq} / \mathrm{kg}$, which is higher than those of Neem seed oil biodiesel $(5.75 \pm 0.02 \mathrm{mEq} / \mathrm{kg})$ showing good quality status in the biodiesel. Standard peroxide values for biodiesel are not stated but all values observed were within the standard value for oil samples of $10-20 \mathrm{mEq} / \mathrm{kg}$ but $30-40 \mathrm{mEq} / \mathrm{kg}$ are associated with a rancid taste [39]. The variation in the values shows the extent deterioration has advanced in the samples and this is used for identifying the onset of oxidative change during which the oxygen $\left(\mathrm{O}_{2}\right)$ molecule penetrates the molecule in the form of a peroxide group $\left(\mathrm{H}_{2} \mathrm{O}_{2}\right)$ [36]. This also is the amount of unstable hydroperoxides (deteriorated biodiesel) when oxygen reacts with fatty esters.

Carbon residue in Neem seed oil was $0.22 \pm 0.02 \%$, which is higher than that of Neem seed oil biodiesel $(0.16 \pm 0.01 \%$ ), but above the permissible limit of $0.05 \%$ max of ASTM, 2011/EN, 2010 . Higher values indicate the presence of higher organic particles in the sample which could lower the reaction [40].

Molecular weight of Neem seed oil $375.50 \mathrm{~g} / \mathrm{mole}$, which is higher than that in Neem seed oil biodiesel (289.30 g/mole) but differs in ASTM/EN standards because of its dependence on the free fatty acid present coupled with the saponification value. Transesterification of vegetable oil reduces the molecular weight and viscosity of the oil, and improve its volatility to a suitable range for diesel engines [41].

Sulphur in Neem seed oil was $7.30 \pm 0.30 \mathrm{mg} / \mathrm{kg}$, which is higher than that of Neem seed oil biodiesel

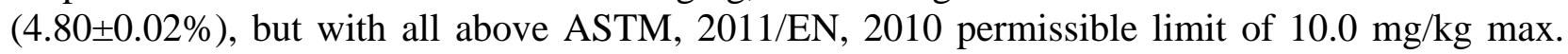
Potassium in Neem seed oil was $0.05 \pm 0.00 \mathrm{mg} / \mathrm{kg}$ which is lower than that of Neem seed oil biodiesel $(0.02 \pm 0.00 \mathrm{mg} / \mathrm{kg})$, but all are within limit of $0.01-0.20 \mathrm{mg} / \mathrm{kg}$. Aluminium in Neem seed oil was $0.33 \pm 0.10 \mathrm{mg} / \mathrm{kg}$ which is higher than that of Neem seed oil biodiesel $(0.28 \pm 0.02 \mathrm{mg} / \mathrm{kg})$, but within ASTM, (2008)/EN, (2009) standard of $0.50 \mathrm{mg} / \mathrm{kg}$ and less than that of Taiwo et al. (2016). This indicates the safety and rate of reduction in degradation because metals initiate spoilage that affects shelf-life stability of the samples and also their bio-accumulation in the body over time can lead to serious harmful effect and health risk.

\section{Conclusion}

There seems to be no danger in terms of neem seed reserves and potential capacity for future sustainability since its going be part of the substitute for biodiesel production and could also be 
blended with flammable solvents so no total dependence on it.

The physico-chemical and fuel properties characterized have most values within the ASTM, (2008)/EN, (2009) standards except in the Neem seed oil. The Neem seed oil can be used for biodiesel production after pre-treatment to reduce the concentration of some of the parameters that are above permissible limits and it can also be used in soap production.

Neem seed oil biodiesel can be a major contributor now and thereafter in the future by meeting the demand expected of petroleum diesel. Finally, also based on these fuel properties, it can used with little or no modification on diesel engines and plants.

\section{Acknowledgements}

The authors acknowledge the grant from TETFUND, Nigeria through the Management of Moshood Abiola Polytechnic and administered by the Directorate of Research and Development to carry out this laudable research in alternative renewable energy.

\section{References}

[1] R. A. Dias, C. R. Mattos, and J. A. P. Balestieri (2004). Energy education: Breaking up the rational energy use barriers. Energy Policy 32(11), 1339-1347

[2] A. G. Mohod, S. Jain, Y. P. Khandetod (2015). Potential assessment and characterization of cashew nut shells as fuel. J. Biofuels Bioenergy. 1(1):71. https://doi.org/10.5958/2454-8618.2015.00009.7

[3] A. Krstulovic and F. Barbiar F. (2008). Bio-diesel and/or hydrogen in Croatia - Challenge and Necessity. In Barbiar F., Ulgiaty S. (eds). Sustainable Energy Production and Consumption. Benefits, Strategies and Environmental Costing. Springer Science and Business Media B.V., Dordrecht, Netherlands

[4] S. Ladanai and J. Vinterbäck (2009). Global potential of Sustainable Biomass for Energy. SLU, Swedish University of Agricultural Sciences, Department of Energy and Technology. Rapport 013 (Institutionen energi och teknik, SLU). ISSN 1654-9406

[5] D. Skambracks (2007). Financing of bioenergy: sustainability in credit allocation? Conference Information: Naturschutz und Landwirtschaft im Dialog: "Biomasseproduktion - ein Segen fur die Land(wirt)schaft?" Tagung am Bundesamt fur Naturschutz - Internationale Naturschutzakademie Insel Vilm 12. bis 15. Marz. BfN Skripten (Bundesamt fur Naturschutz) 211, 76-88

[6] D. Roberts. (2007). Globalization and Its Implications for the Indian Forest Sector. TIFAC/IIASA Joint Workshop "Economic, Societal and Environmental Benefits Provided by the Indian Forests", New Delhi, India

[7] S. Silveira (2005). Bioenergy - Realizing the potential. Swedish Energy Agency, Eskilstuna, Sweden.

[8] S. Silveira and D. Foster (2008). "Availability of Biomass across the Globe" Retrieved from http://www.forestencyclopedia.net/ on June, 12, 2018

[9] DOE, (2002). Biodiesel Green Diesel Fuel," DOE/GO-102001-1449. National Renewable Energy Lab, US Department of Energy

[10] I. P. Ogbuewu, V. U. Odoemenam, H. O. Obikaonu, M. N. Opara, O. O. Emenalom, M. C. Uchegbu, I. C. Okoli, B. O. Esonu and M. U. Iloeje (2011). The Growing Importance of Neem (Azadirachta indica A.Juss) in Agriculture, Industry, Medicine and Environment. A Review, Research Journal of Medicinal Plants, 5: pp.230245

[11] A.O.A.C. (2000). Official methods of Analysis of the Association of Official Analytical Chemists, $11,15^{\text {th }}$ edition, sec. 985.29. The Association Arlington, VA

[12] A.O.C.S. (2003). Official Methods of the American Oil Chemists' Society, 3rd Edition, Champaign, Illionois

[13] ISO EN660, (1996). Animal and Vegetable fats and oils - determination of acid value and acidity, International Standards Organisations, Geneva, Switzerland

[14]F. Joshua (2013). Production of Biodiesel (B100) from Jatropha Oil Using Sodium Hydroxide as Catalyst. Journal of Petroleum Engineering, 956479: p 6

[15] A.O.A.C. (2005). Official Methods of Analysis of the Association of official Analytical Chemists, 16th Edition, Washington DC30033

[16]S. V. Ghadge and H. Raheman (2006). Process optimization for biodiesel production from mahua (Madhucaindica) oil using response surface methodology. Bioresource Technology, 97: pp. 379-384

[17] G. Knothe (2006). Analyzing biodiesel: Standards and other methods. Journal of Am. Oil Chem. Soc., 83(10), pp. $823-833$

[18] O. O. Oniya and A. I. Bamgboye (2014). Production of biodiesel from groundnut (Arachis hypogea L.) oil. Agric. Eng. Int:CIGR Journal, (16) 1: pp. 143-150 
Taiwo, A. $G$ et al./ NIPES Journal of Science and Technology Research

2(2) 2020 pp. $178-187$

[19] ASTM D613-18a, (2008). Standard Test Method for Cetane Number of Diesel fuel oil. ASTM International, West Conshohocken, PA. D02.01. Vol. 05.05 www.astm.org

[20] M. J. Haas (2005). Improving the economies of Biodiesel production through the use of low value Lipids as feedstocks: vegetable oil soapstock. Fuel Process Technol., 86: pp. 1087-1096

[21] R. Dangarembizi, E. Chivandi, S. Dawood, K. H. Erlwanger, M. Gundidza, M. L. Magwa, P. Muredzi and A. Samie (2015). The fatty acid composition and physico-chemical properties of underutilised Cassia abbreviata seed oil. Pakistan Journal Pharmaceutical Sciences, 28(3), pp.1005-1008

[22] A. A. Ibikunle, A. J. Olanrewaju and A. G. Taiwo. (2019). Solvent, Temperature and Time effect on the Yield and Properties of Biodiesel produced from two types of Vegetable oils. Journal of Chemical Society of Nigeria, 44(4), pp. 517-524

[23] ASTM, (2008b). Standard specification for Biodiesel Fuel Blend Stock (B100) for Middledistillate fuels. In: Annual Book of ASTM Standards. American Society for Testing Materials, West Conshohocken, United States. Method D6751-08

[24] American Society for Testing Materials (ASTM), (2011). ASTM D6751-11b. Standard specification for Biodiesel Fuel Blend Stock (B100) for Middle distillate fuels. West Conshohocken (PA), United States. DOI: $<10.1520 / \mathrm{D} 6751-11 \mathrm{~B}$

[25]EN 590, (2009). Automotive Fuels-Diesel-Requirements and Test Methods. European Committee for Standardization, Brussels, Belgium (CEN)

[26] European Committee for Standardization (CEN), (2010). EN 14214 Automotive Fuels-Fatty acid methyl esters (FAME) for Diesel engine-Requirements and Test Methods. Brussels, Belgium (CEN)

[27] A. V. Sustistyo, F. F. Jain and V. F. Sharma (2006). Which way to energy utopia: Nature, 414: pp. 682-684

[28] M. A. Gonabad, M. S. Noghabi and R. Niazmand (2015). Evaluation of Extraction Percentage and Physicochemical Properties of Walnut Oil. Journal of Applied Environmental and Biological Sciences, 4: pp.74-82

[29] E. F. Aransiola, E. Betiku, D. I. O. Ikhuimoregbe and T. V. Ojumu (2011). Production of Biodiesel from crude Neem oil feedstock and its Emission from internal combustion Engines. African Journal of Biotechnology, 11(22), pp. 6178-6186

[30] A. G. Taiwo, N. A. A. Babarinde and A. A. Ibikunle (2016). Physico-chemical and Microbial characterization of Biodiesel (B100) produced from Fresh and Waste Frying Vegetable Oils after six months storage. International Journal of Innovative and Applied Research, 4, (9), pp. 1-11

[31] N. De Lima da Silva, C. B. Batistella, R. M. Filho and M. R. W. Maciel (2009). Biodiesel production from Castor oil: Optimazation of Alkaline Ethanolysis. Energy \& Fuels, 23: pp. 5636-5642

[32] B. R. Moser (2009). Biodiesel Production, Properties and Feedstocks. In Vitro Cell Dev. Biol.-Plant, 45:229266. DOI 10.1007/s11627-009-9204

[33] M. H. Alli, M. Mashud, M. R. Rubel and R. H. Ahmed (2013). Biodiesel from Neem oil as an alternative fuel for Diesel engine. Procedia Engineering, 56: pp. 625-630. www.sciencedirect.com

[34] K. S. Tyson (2001). "Biodiesel Handling and Use Guidelines." National Renewable Energy Laboratory, Report No, NREL/TP-580-30004, Golden (CO)

[35] B. C. Arjun, K. W. Chris and M. S. Rafiqul (2008). Waste cooking oil as an alternative feedstock for biodiesel production. Energies, 1: pp. 3-18

[36] A. E. Atabani, A. S. Silitonga, T. M. I. Irfan Anjum Badruddin, H. H. Mahlia and S. M. Masjuki (2012). A comprehensive review on Biodiesel as an alternative energy resource and its characteristics. Journal of Renewable and Sustainable Energy Reviews, 16: pp. 2070-2093

[37] T. B. Reed, M. S. Graboski and S. Gaur (1994). Development and Commercialization of Oxygenated diesel fuels from waste vegetable Oil. Biomass Bioenergy, 3, pp. 11-115

[38] E. Choe and D. B. Min (2007). Chemistry of Deep-Fat Frying Oil. Journal of Food Science, 72: pp. 78-86

[39] ISO 17025, (2017). International Standard Organisation Standard for Biological and Chemical Testing, PJLA Testing Accreditation No 72716. Murray-Brown Laboratories Incorporated, 2019, all rights reserved

[40]F. J. Sprules and D. Price (2010). Production of fatty esters. US Patent 2: pp. 366-494

[41] O. A. Aworanti, S. E. Agarry, and A. O. Ajani (2012). A Laboratory Study of the Effect of Temperature on Densities and Viscosities of Binary and Ternary Blends of Soybean Oil,Soy Biodiesel and Petroleum Diesel Oil. Advances in Chemical Engineering and Science, 2: pp. 444-452 